\title{
Screening of Tomato Genotypes for Early Blight Disease Resistance in Tomato (Solanum lycopersicum L.)
}

\author{
Suresh Kumar Sah", Anand Kumar Singh, B. K. Singh, Kalyan Barman and A. K. Pal \\ Department of horticulture, Institute of Agricultural Sciences, BHU, Varanasi, India \\ *Corresponding author
}

\section{A B S T R A C T}

\section{Keyw ords \\ Early blight disease, \\ Screening, \\ Resistant, Natural \\ field condition, \\ Yield}

Article Info

Accepted:

24 September 2020

Available Online:

10 October 2020
Early blight is the most devastating disease of tomato it is caused by pathogens i.e. Alternaria solani. In tropical and subtropical countries it creates hazardous effect. It is also a common problem in United Kingdom, Australia, India, Nepal and United States. It is one of the most common foliar diseases of tomatoes. The disease can occur over a wide range of climatic conditions, but is most prominent in areas with heavy dew, rainfall and high relative humidity. Every year sever disease appears in north India. Early blight disease mostly effects leaf, stem, and rotening of the apical parts of fruit is very serious and damaging symptoms. Entire tomato crop loss occurs during severe occurrence of this disease of tomato. Fourteen genotypes including one check variety of tomatoes were involved in this study for the identification of highly resistant (HR), resistant(R), moderately resistant (MR), moderately susceptible (MS) and susceptible (S) reaction of tomato genotypes under natural field condition. Screening trail was done in multiple replications during two Rabi seasons 2016-17 and 2017-18 at Vegetable Research Farm, Department of Horticulture, Institute of Agricultural Sciences, Banaras Hindu University, Varanasi, India. Genotype EC-520061 was found highly resistant during both the year 2016-17 and 2017-18. Thus it was proved from our research that the genotype EC-520061 was stable and consists of highly resistant gene against early blight disease of tomato under natural field condition. However, resistant reaction was recorded in two genotypes during Rabi 2016-17. But susceptible reaction was proved to be in three genotypes during 2017-18.

\section{Introduction}

Tomato native to the Andean region of South America is one of the most common horticultural crops and cultivated throughout the world. It can be grown in a wide range of climates from tropical to temperate; it also can be cultivated under cover conditions when outdoor temperatures are not favorable. Tomato is the world's second most consumed vegetable after potato (Foolad, 2007). The total world production of tomato is 161.7 million metric tons with a value of $\sim \$ 59$ billion. USA tomato production contributes 13.2 million metric tons with a value of $\$ 5$ billion to the total world production. The India ranks in second position in the total world production of tomato after China (FAOSTAT, 2017). Tomatoes are consumed in several ways: fresh, mixed in other food 
items or processed and canned as sauce, ketchup, juice, salsa, paste, soup and pickle. Tomato is the richest source of vitamin A and $\mathrm{C}$ and supplies a sufficient amount of the antioxidant lycopene pigment that helps to protect the body against cancer and heart disease (Van Breemen, 2008). Because of its wide use and nutritional values, there is a high demand for both fresh market and processed tomato varieties. Higher production of tomato is therefore required to fulfill the everincreasing demand. Early blight is the most destructive disease of tomato in India and caused by pathogens i.e. Alternaria solani. It is also a common problem in United Kingdom, Australia and United States. Symptoms of early blight appear on all above ground parts of the plant. The disease appears first as spots on leaflet; spots are circular to angular, dark brown to black and range from pin head to $4 \mathrm{~mm}$ in diameter. Leaf spots are scattered, brown with conspicuous concentric rings surrounded by chloratic halo on their outer margin due to host specific toxin produced by the pathogen.

The stem lesions are usually restricted elongations and sunken. The fruit symptoms initiate generally at the end of February and radiate between attachment of calyx and fruit are dark brown depressed, firm with distinct concentric rings. Mostly disease appears in vegetative phase of the plant growth before flowering and is more prevalent between flowering to fruit ripening and continue till the crop completely senescent Kumar et al., (2015). It is one of the most common foliar diseases of tomatoes. The disease can occur over a wide range of climatic conditions, but is most prominent in areas with heavy dew, rainfall and high relative humidity. On tomato it causes damping-off of seedlings, later collar rot, leaf spots, stem lesions and fruit rot. Infection of the plants can result in a complete loss of the crop as yields are reduced by destruction of foliage and the fruits are damaged directly by the pathogen and by sun blotch on defoliated plants (Rotem, 1994). Early blight control is based on crop rotation, removal and destruction of crop debris from previous crops, staking, mulching, and timely application of fungicides. (Mary Ann Hansen, 2009).

\section{Materials and Methods}

The experimental material for this study consisted of fourteen genotypes of tomato, which were selected based on their per se performance for various traits. Screening of early blight for natural infection caused by Alternaria solani was conducted to screen fourteen genotypes of tomato with one check variety (DVRT-1) at Vegetable Research Farm, Department of Horticulture, Institute of Agricultural Sciences, Banaras Hindu University, Varanasi, India. Varanasi, India. Located in the middle Gangetic plain (latitude: $25^{0} 19^{\prime} 59^{\prime \prime}$ longitude: $83^{0} 00^{\prime} 00^{\prime \prime}$ EN elevation above sea level: $77 \mathrm{~m}$ ) in the eastern part of the state of Uttar Pradesh. It is located in the Indo-Gangetic Plains of North India. The genotypes were provided by ICAR, Indian Institute of Vegetable Research (IIVR), Varanasi, UP, India. The experimental material involved in this experiment was genetically diverse genotypes (EC-620421, EC-620536, EC-620494, EC620500, EC-620520, EC-620502, EC-552141, EC-538405, EC-570028, EC-273966, EC520061, EC-520058, Hisar Arun and DVRT1). During Rabi seasons 2015-16, 2016-17 and 2017-18. Twenty plants were selected for each treatment and percent disease index (PDI) was assessed by using 0-5 scale (Pandey et al., 2003) described as in (Table 1).

Disease severity was scored on a five-point scale (Pandey et al., 2003) and classification of reaction types.

Percent disease index (PDI) = Sum of individual ratings $x 100$

Total No. of observation x Maximum rating grade 


\section{Results and Discussion}

The diseases caused by fungi Alternaria solani cause considerable losses to the tomato. The early blight screening is presented in Table 2. Under field conditions, it leads to leaf and stem blight which causes defoliation of plant resulting in drastic reduction in fruit yield, while fruit infection in the field and after harvest results in rotting of tomato fruits, affecting the marketable quality. Field trail was conducted in natural condition at the Vegetable Research Farm, Department of Horticulture, Institute of Agricultural Sciences, Banaras Hindu University, Varanasi, UP, India during Rabi 2015-2016, 2016-2017 and 2017-2018. The reactions were categorized as highly resistant (HR), resistant(R), moderately resistant (MR), moderately susceptible (MS) and susceptible
(S). Significant difference in-between different genotypes were observed on the basis of per cent disease infection (PDI) record which ranged from highly resistant genotype to susceptible check genotype i.e. genotype EC-520061 (4.42 \%) with the yield of $353.17 \mathrm{q} / \mathrm{ha}$ was proved to be highly resistant but the check genotype DVRT-1 $(68.31 \%)$ with the yield of $291.67 \mathrm{q} / \mathrm{ha}$ was proved to be susceptible during the year 20162017. However, during the year 2017-2018 different trained was found the same genotype EC-520061 (3.72\%) with the yield of 354.27 $\mathrm{q} / \mathrm{ha}$ was found to be highly resistant. Thus it is proved from our experiment that the genotype EC-520061 expressed the stable and highly resistant reaction against early blight disease of tomato in natural field condition during both years 2016-2017 and 2017-2018.

Table.1 Early blight screening under field (Natural) condition

\begin{tabular}{|l|c|c|c|}
\hline \multicolumn{1}{|c|}{ Symptoms } & $\begin{array}{c}\text { Symptoms } \\
\text { severity grade }\end{array}$ & $\begin{array}{c}\text { Percent Disease } \\
\text { index(PDI) }\end{array}$ & Reaction \\
\hline $\begin{array}{l}\text { Free from infection } \\
\text { One or two necrotic spots on } \\
\text { a few lower leaves of plant. }\end{array}$ & 1 & $0-5$ & Highly resistant \\
\hline $\begin{array}{l}\text { A few isolated spots on leaves, } \\
\text { covering nearly 5\%-10\% of } \\
\text { the surface area of the plant. }\end{array}$ & 2 & $12.1-25$ & Resistant \\
\hline $\begin{array}{l}\text { Many spots coalesced on the } \\
\text { leaves covering 25\% of the } \\
\text { surface area of the plant. }\end{array}$ & 3 & & \\
\hline $\begin{array}{l}\text { Irregular, blighted leaves and } \\
\text { sunken lesions with } \\
\text { prominent concentric rings on } \\
\text { the stem, petiole, and fruits, } \\
\text { covering 40\% -50\% of the } \\
\text { surface area. }\end{array}$ & 4 & & Moderately \\
\hline $\begin{array}{l}\text { Whole plant blighted; Leaves } \\
\text { and fruits starting to fall; } \\
\text { foliar part free of disease. }\end{array}$ & 5 & & Susceptible \\
\hline
\end{tabular}


Table.2 Per cent disease index, disease reactions and yield of thirteen genotypes for early blight disease resistance in tomato in natural field condition 2016-2017 and 2017-2018

\begin{tabular}{|c|c|c|c|c|c|c|}
\hline \multirow[b]{2}{*}{ Treatments } & \multicolumn{3}{|c|}{ 2016-17 } & \multicolumn{3}{|c|}{ 2017-18 } \\
\hline & $\begin{array}{l}\text { PDI } \\
(\%)\end{array}$ & DR & $\begin{array}{c}\text { Fruit yield } \\
\text { (q/ha) }\end{array}$ & $\begin{array}{l}\text { PDI } \\
(\%)\end{array}$ & DR & $\begin{array}{l}\text { Fruit yield } \\
\text { (q/ha) }\end{array}$ \\
\hline \multicolumn{7}{|l|}{ Genotypes } \\
\hline EC-620421 & 54.42 & $\mathrm{~S}$ & 294.07 & 48.51 & $\mathrm{~S}$ & 305.00 \\
\hline EC-620536 & 48.12 & MS & 304.67 & 43.91 & MS & 403.00 \\
\hline EC-620494 & 45.21 & MS & 307.00 & 46.97 & MS & 319.67 \\
\hline EC-620500 & 24.56 & MR & 309.00 & 20.49 & MR & 309.67 \\
\hline EC-620520 & 32.52 & MS & 305.13 & 24.13 & MS & 305.33 \\
\hline EC-620502 & 37.31 & MS & 304.47 & 43.75 & MS & 296.67 \\
\hline EC-552141 & 10.06 & $\mathrm{R}$ & 334.67 & 8.76 & $\mathrm{R}$ & 336.33 \\
\hline EC-538405 & 61.44 & $\mathrm{~S}$ & 284.71 & 54.45 & $\mathrm{~S}$ & 293.67 \\
\hline EC-570028 & 19.04 & MR & 322.80 & 20.97 & MR & 323.67 \\
\hline EC-273966 & 17.57 & MR & 334.10 & 19.87 & MR & 333.45 \\
\hline EC-520061 & 4.42 & HR & 353.17 & 3.72 & HR & 354.27 \\
\hline EC-520058 & 8.50 & $\mathrm{R}$ & 349.40 & 7.93 & $\mathrm{R}$ & 352.28 \\
\hline Hisar Arun & 27.24 & MS & 403.50 & 33.09 & MS & 406.47 \\
\hline Check-DVRT-1 & 68.31 & $\mathrm{~S}$ & 291.67 & 63.43 & $\mathrm{~S}$ & 292.97 \\
\hline $\mathbf{S E}(d)$ & 0.861024 & & 4.386539 & 2.237255 & & 2.86121 \\
\hline $\mathrm{CV} \%$ & 3.75414 & & 1.163691 & 9.00541 & & 0.759426 \\
\hline SE. m. \pm & 0.608836 & & 3.101751 & 1.581978 & & 2.023181 \\
\hline CD & 1.712241 & & 8.72015 & 4.449027 & & 5.687897 \\
\hline
\end{tabular}

$\mathrm{PDI}=$ Per cent disease index,

$\mathrm{DR}=$ Disease reaction,

$\mathrm{R}=$ Resistant,

MR=Moderately Resistance,

$\mathrm{MS}=$ moderately susceptible,

$\mathrm{S}=$ Susceptible

Similar result was also reported by Singh et al., (2011), they observed highly resistant reaction against the early blight disease in the genotypes EC-520057, EC-520058, EC520059, EC-520061, EC-508765, EC-538394, H-88-78-1 and EC-501583. "USDA researcher R. E. Webb" in " 1967 ”, 'identified field resistance in tomato breeding genotype 67B833' (Barksdale, 1971; Barksdale and Stoner, 1973; USDA, 2007). Barksdale (1969) did screening of many breeding 'lines and accessions of S. lycopersicum' and found a resistant accession (PI138630) that was successfully utilized for 'early blight resistant breeding programme'. Thus, the 'development and release of resistant breeding lines71B2 and (C1943) (Barksdale and Stoner, 1977) become possible. "C-1943" was used as a 'source of early blight resistance' in developing breeding lines NC63EB, NC-870, NCEBR-2, NCEBR-3 and NCEBR-4 (Gardner, 1988) Respectively, however '71B2 was also used as a source of resistance' in developing tomato breeding lines NCEBR-5 and NCEBR-6 (Gardner, 2000). However, during 2016-2017 two genotypes showed resistant reaction i.e. EC$552141(10.06 \%)$ yielding $334.67 \mathrm{q} / \mathrm{ha}$ and 
EC-520058 (8.50\%) yielding 349.40 q/ha. While, during 2017-2018 again same two genotypes showed resistant reactions namely EC-552141 (8.76\%) yielding $336.33 \mathrm{q} / \mathrm{ha}$ and EC-520058 (7.93\%) yielding $352.28 \mathrm{q} / \mathrm{ha}$. Thus these two genotypes were observed stable for resistant reaction in both the year in natural condition. These findings are similar with the report of Kanjilal et al., (2000) in West Bengal. Alsafadi et al., (2012) was recorded disease level based on a 1-9 scale. Results showed that cultivars Bosfer and Daher aljabal had a high level of resistance to early blight disease. During 2016-2017 genotypes which showed moderately resistant reaction are EC-620500 (24.56\%) yielding 309 q/ha, EC-570028 (19.04 \%) yielding 322.80 q/ha, EC-273966 (17.57 \%) yielding 334.10 q/ha. While, during 2017-2018 genotypes which showed moderately resistant reaction are EC-620500 (20.49 \%) yielding 309.67 q/ha, EC-570028 (20.97 \%) yielding $323.67 \mathrm{q} / \mathrm{ha}$ and EC-273966 (19.87 \%) yielding $333.45 \mathrm{q} / \mathrm{ha}$. Similar findings were also reported by Upadhyay et al., (2009) they found that EC-165690, EC- 163681, EC136711, EC -163683, LE- 16, LE -35, LE 54, LE 85, LE-172 and LE-189 were moderately resistant (PDI 25.1-40 \%). were supported by our study and reported for disease severity and host resistance of the plants. Five genotypes showed moderately susceptible reactions during 2016-2017 with their PDI values namely EC-620536 (48.12\%) yielding 304.67 q/ha, EC-620494 (45.21 \%) yielding 307 q/ha, EC-620520 (32.52 \%) yielding 305.13 q/ha, EC-620502 (37.31 \%) yielding $304.47 \mathrm{q} / \mathrm{ha}$ and Hisar Arun (27.24 \%) yielding $403.50 \mathrm{q} / \mathrm{ha}$. Whereas, five genotypes showed moderately susceptible reaction during 2017-2018. They are EC$620536(43.91 \%)$ yielding $403.00 \mathrm{q} / \mathrm{ha}$, EC$620494(46.97 \%)$ yielding $319.67 \mathrm{q} / \mathrm{ha}$, EC$620520(24.13 \%)$ yielding 305.33 q/ha, EC$620502(43.75 \%)$ yielding $296.67 \mathrm{q} / \mathrm{ha}$ and Hisar Arun (33.09 \%) yielding $406.47 \mathrm{q} / \mathrm{ha}$.
Three genotypes showed susceptible reaction during 2016-2017 with their PDI values namely EC-620421 (54.42 \%) yielding 294.07 q/ha, EC-538405 (61.44 \%) yielding 284.71 q/ha and DVRT-1 (68.31 \%) 291.67 q/ha. While, three genotypes showed susceptible reaction during 2017-2018 i.e. EC-620421 $(48.51 \%)$ yielding $305.00 \mathrm{q} / \mathrm{ha}$, EC-538405 $(54.45 \%)$ yielding $293.67 \mathrm{q} / \mathrm{ha}$ and DVRT-1 (63.43\%) $292.97 \mathrm{q} / \mathrm{ha}$. Thus we had observed similar trends in both years for resistant and susceptible in genotypes. Similar results were observed by Kanjilal et al., (2000). Yield losses up to $79 \%$ due to early blight damage were reported from Canada, India, USA, and Nigeria (Datar and Mayee 1981); Sherf and MacNab1986; Kalloo and Banerjee (1993); Gwary and Nahunnaro 1998; and Vloutoglou (1999). Similar reports were also provided by Singh, A. K. and Singh, K. P. 2000, Singh et al., 2007, Singh et al., 2008, Kumar et al., 2017.

\section{References}

Alsafadi, F., Al-Fadil, T. A. and Trabi, B. A. 2012. Evaluation of some local tomato cultivars reaction to early blight disease caused by Alternaria solani Arab J. Plant Protection. 30(1): 139-141.

Anonymous, FAOSTAT Database. 2017. Available online, http//faostat.org/site/ 339/defaultaspx., accessed on 19 September.

Barksdale, T. H. and Stoner, A. K. 1977. A study of the inheritance of tomato early blight. Plant Dis. Rep. 61: 63-65.

Barksdale, T. H. and Stoner, K. 1973. Segregation for horizontal resistance to tomato early blight. Plant Dis. Rep. 37: 964-965.

Barksdale, T. H. 1971. Field evaluation for tomato early blight resistance. Plant Dis. Rep. 55: 807-809.

Barksdale, T. H. 1969. Resistance of tomato seedling to early blight. Phytopathol. 59: 443-446.

Foolad M.R., Merk H.L., Ashrafi H. 2007. Genetics, genomics and breeding of late blight and early blight resistance in tomato. 
Crit. Rev. Plant Sci., 27:75-107.

Gardner, R. G. 'Plum Dandy'. 2000. A Hybrid Tomato and Its Genotypes, NC EBR-5 and NC EBR-6. Hort. Sci. 35: 962-963.

Gardner, R. G. NC EBR-1 and NC EBR-2 1988. Early blight resistant tomato breeding lines. Hort. Sci. 23: 779-781.

Gwary, D.M, Nahunnaro, H. 1998. Epiphytotics of early blight of tomatoes in Northeastern Nigeria, Crop Prot, 17, 619-624.

Kalloo G., Banerjee M.K. 1993. Early blight resistance in Lycopersicon esculentum Mill. transferred from L. pimpinnellifolium (L.) and L. hirsutum $f$. glabratum Mull. Gartenbauwissenschaft., 58: 238-240.

Kanjilal, S., Samaddar, K. R. and Samajapati, N. 2000. Field disease potential of tomato cultivation in West Bengal. J. Mycopathological Research. 38(2):121-123.

Kumar, P., Singh, A. K., Rai, N. K., Singh, R. K. and Singh, T. K. 2017. Transfer of tomato leaf curl virus (ToLCV) resistance from Solanum pimpinellifolium to Solanum lycopersicum L. New Agriculturist. 28(1): 14.

Kumar, V., Naeem, F. and Kumar, A. 2015. Evaluation of Different Germplasms/ Cultivars of Tomato against Early Blight (Alternaria solani) in Field Conditions and by Artificial Inoculation Method: A Review Article. Open Access Library Journal, 2: e1548. http://dx.doi.org/10.4236/oalib. 1101548 .

Mary, A.H. 2009. Virginia Cooperative Extension, Publication, 450-708.

Pandey, K.K., Pandey, P. K., Kalloo, G. and Banerjee, M. K. 2003. Resistance to early blight of tomato with respect to various parameters of disease epidemics, J. Gen. Pl. Pathol., 69, 364-371.

Rotem, J., Reichert, I. 1994. Dew a principal moisture factor enabling early blight epidemics in a semiarid region of Israel, Plant Dis Rep, 48, 211-215.

Sherf, A.F. and MacNab, A.A. 1986. Vegetable diseases and their control. John Wiley and Sons, New York, 634-640.

Singh, A. K. and Singh, K. P. 2000. Screening for disease incidence of yellow vein mosaic virus in okra [Abelmoschus esculentus (L.) Moench]. Vegetable Science. 27 (1): 72-75.

Singh, A. K., Sharma, J. P., Kumar, S. and Sharma N. 2007. Screening okra against yellow vein mosaic virus under sub-tropical conditions. Haryana Journal of Horticulture. 36 (3\&4): 294-296.

Singh, B., Singh, B. K. and Singh, A. K. 2008. Evaluation and screening against YVMV of biological gene pool of okra [Abelmoschus esculentus (L.) Moench] for yield and yield traits. Environment and Ecology. 26 (2A): 894-898.

Singh, P. C., Kumar, R., Major, S. 2011. Ashutosh, R., Singh, M. and Rai, C. Identification of resistant sources against early blight disease of tomato. Indian $\mathrm{J}$. of Hort. 68(4): 516-521.

Upadhyay, P., Singh, P. C., Sinha, B., Singh, M., Kumar, R., Pandey, K. K. and Mathura, R. 2009. Sources of resistance against early blight (Alternaria solani) in tomato (Solanum lycopersicum). Indian J. of Agri. Sci. 79(9): 752-753.

USDA. 2007. Vegetable Lab History. Beltsville, MD

Van, Breemen, R.B. and Pajkovic, N. 2008. Multitargeted therapy of cancer by lycopene, Cancer Lett., 269 (2), 339-51.

Vloutoglou I. 1999. Evaluation of tomato cultivars and crosses for resistance to Alternaria solani infection, Test Agrochem Cult., 20, $48-49$.

\section{How to cite this article:}

Suresh Kumar Sah, Anand Kumar Singh, B. K. Singh, Kalyan Barman and Pal, A. K. 2020. Screening of Tomato Genotypes for Early Blight Disease Resistance in Tomato (Solanum lycopersicum L.). Int.J.Curr.Microbiol.App.Sci. 9(10): 2909-2914.

doi: https://doi.org/10.20546/ijcmas.2020.910.350 